\title{
Antinuclear antibodies and the diagnosis of systemic lupus erythematosus in patients with acute intermittent porphyria
}

\author{
S A Allard, P J Charles, A L Herrick, K E L McColl, J T Scott
}

\begin{abstract}
To investigate the previously postulated association of systemic lupus erythematosus (SLE) and porphyria 38 patients with various types of porphyria were investigated for clinical and laboratory evidence of a connective tissue disease. Antinuclear antibodies (ANAs) were found in $8 / 15(53 \%)$ patients with acute intermittent porphyria. These patients were more likely to have had a recent acute attack of porphyria, but only one patient had clinical evidence of SLE. Antinuclear antibodies were not found in any patients with latent acute intermittent porphyria or appreciably in any of the other types of porphyria studied. This finding of ANAs in patients with acute intermittent porphyria may explain the previously described association with SLE. Strict diagnostic criteria need to be used in any one patient as these two disorders have many similar clinical manifestations.
\end{abstract}

The co-occurrence of systemic lupus erythematosus (SLE) and porphyria has been described in several case reports. ${ }^{1-6}$ Although a genetic or environmental link between these diseases has been proposed, ${ }^{2}$ this has never been established. In this study we looked for clinical and laboratory evidence of connective tissue disease in patients with various types of porphyria.

Patients and methods

Thirty eight patients with porphyria, diagnosed at three major referral centres in the United Kingdom, were studied. These included 15 patients with acute intermittent porphyria, seven with porphyria cutanea tarda, five with erythropoietic protoporphyria, five with variegate porphyria, one with hereditary coproporphyria, and five with latent acute intermittent porphyria-that is, relatives with deficiency of porphobilinogen deaminase but yet to have clinically manifest disease.

History and examination were directed to investigate for a connective tissue disease in these patients. Laboratory indices measured included full blood count, erythrocyte sedimentation rate (ESR), serum immunoglobulins, and rheumatoid factor. All serum samples were screened by direct immunofluorescence for antinuclear antibodies (ANAs) on $\mathrm{HEp}_{2}$ cells and by counterimmunoelectrophoresis for antibodies to the soluble antigens nRNP, Sm, SS-A (Ro), and SS-B (La), and single stranded DNA (ssDNA). Fluorescent ANA positive sera were also tested for antibodies to double stranded
DNA (dsDNA) (Farr assay, Amersham International, England and Crithidia luciliae immunofluorescence) and to DNA-protein complex (microhaemagglutination assay). The specificity of antibodies to soluble antigens (fluorescent ANA or counterimmunoelectrophoresis positive sera) was confirmed by double immunodiffusion. The ANA positive sera were further investigated for antibodies to histones according to the method of Tan et al. ${ }^{7}$ Antibodies to cardiolipin (Sigma) were measured by enzyme linked immunosorbent assay (ELISA).

The relation between ANA positivity and disease activity in acute porphyria was further investigated by preincubation of pathological concentrations $(5-100 \mu \mathrm{mol} / \mathrm{l})$ of $\delta$-aminolaevulinic acid and porphobilinogen (Sigma) with the acute intermittent porphyria (ANA positive and negative) sera before standard immunofluorescence on $\mathrm{HEp}_{2}$ cells. Preincubation was for 15 minutes at room temperature in the dark. Serum samples from patients with SLE and normal samples were included as positive and negative controls.

\section{Results}

The main positive findings of this study are confined to the patients with acute intermittent porphyria. Of these 15 patients, eight $(53 \%)$ were found to have a positive ANA test. The fluorescence pattern was homogeneous in seven and nucleolar in one. There were no clinical differences in age, sex, or disease duration between the ANA positive and ANA negative patients (table 1). Serum samples were obtained during or soon after an acute attack in six (75\%) of the ANA positive patients compared with three (43\%) of ANA negative patients. Only two

Table 1: Comparison of clinical details of patients with acute intermittent porphyria with or without antinuclear antibodies (ANAs)

\begin{tabular}{|c|c|c|}
\hline & $\begin{array}{l}\text { ANA } \\
\text { positive } \\
(n=8)\end{array}$ & $\begin{array}{l}\text { ANA } \\
\text { negative } \\
(n=7)\end{array}$ \\
\hline $\begin{array}{l}\text { Age (years) } \\
\text { Mean } \\
\text { Range } \\
\text { Sex } \\
\text { Disease duration (years) }\end{array}$ & $\begin{array}{l}37 \cdot 4 \\
26-51 \\
7 F: 1 M\end{array}$ & $\begin{array}{l}37 \cdot 6 \\
22-82 \\
7 F\end{array}$ \\
\hline $\begin{array}{l}\text { Mean } \\
\text { Range }\end{array}$ & $\begin{array}{l}9 \cdot 75 \\
1-37\end{array}$ & $\begin{array}{l}8 \cdot 86 \\
1-40\end{array}$ \\
\hline $\begin{array}{l}\text { Recent acute attackt } \\
(\text { No }(\%))\end{array}$ & $6(75)$ & $3(43)$ \\
\hline $\begin{array}{l}\text { Possible coexistent } \\
\text { connective tissue disease }\end{array}$ & $\begin{array}{l}\text { SLE* (1) } \\
\text { Still's disease (1) } \\
\text { Gout (1) }\end{array}$ & Arthralgias (1) \\
\hline
\end{tabular}

*SLE=systemic lupus erythematosus. †Within six weeks. 
Table 2: Laboratory investigations of patients with acute intermittent porphyria

\begin{tabular}{|c|c|c|c|c|c|c|c|}
\hline $\begin{array}{l}\text { Patient } \\
\text { No }\end{array}$ & $\underset{(m m / h)}{E S R t}$ & $\gamma$-Globulins & $R F t$ & $\begin{array}{l}A N A t \\
\left(H E p_{2}\right)\end{array}$ & $\begin{array}{l}\alpha C L t \\
(n<15)\end{array}$ & Other antibodies & \\
\hline $\begin{array}{l}\text { ANA positive } \\
1^{*} \\
2^{*} \\
3^{*} \\
4 \\
5^{*} \\
6^{*} \\
7^{*} \\
8\end{array}$ & $\begin{array}{l}72 \\
12 \\
\text { NDt } \\
38 \\
35 \\
11 \\
23 \\
57\end{array}$ & $\begin{array}{l}\uparrow \mathbf{I g G} \\
\mathbf{N f} \\
\mathbf{N D} \\
\mathbf{N} \\
\uparrow \mathbf{I g A} \\
\uparrow \mathbf{I g M} \\
\mathbf{N} \\
\mathbf{N}\end{array}$ & $\begin{array}{l}\text { +ive } \\
\text {-ive } \\
\text {-ive } \\
\text {-ive } \\
\text {-ive } \\
\text {-ive } \\
\text {-ive } \\
\text {-ive }\end{array}$ & $\begin{array}{l}+++(\mathbf{H}) \dagger \\
++(\mathbf{H}) \\
\quad+(\mathbf{H}) \\
\quad+(\mathbf{H}) \\
++(\mathbf{H}) \\
\quad+(\mathbf{H}) \\
\quad+(\mathbf{H}) \\
+++(\mathbf{N u c})+\end{array}$ & $\begin{array}{l}85 \\
\mathbf{N} \\
\mathbf{N} \\
29 \\
\mathbf{N} \\
37 \\
\mathbf{N} \\
\mathbf{N}\end{array}$ & dsDNA; SS-A $\dagger$ & (Still's disease) \\
\hline $\begin{array}{l}\text { ANA negative } \\
9 \\
10^{*} \\
11^{*} \\
12^{*} \\
13 \\
14 \\
15\end{array}$ & $\begin{array}{l}\text { e } \\
15 \\
\text { ND } \\
24 \\
6 \\
20 \\
\text { ND } \\
\text { ND }\end{array}$ & $\begin{array}{l}\mathbf{N} \\
\mathbf{N} \\
\mathbf{N D} \\
\mathbf{N} \\
\mathbf{N} \\
\mathbf{N D} \\
\mathbf{N D}\end{array}$ & $\begin{array}{l}\text {-ive } \\
\text {-ive } \\
\text { ND } \\
\text {-ive } \\
\text {-ive } \\
\text {-ive } \\
\text {-ive }\end{array}$ & $\begin{array}{l}- \\
- \\
- \\
- \\
- \\
-\end{array}$ & $\begin{array}{l}25 \\
28 \\
N \\
N \\
N \\
N \\
N\end{array}$ & $\alpha$-mito† & (Arthralgias) \\
\hline
\end{tabular}

*Indicates an acute attack within six weeks.

+ESR =erythrocyte sedimentation rate; $R F=$ rheumatoid factor; $A N A=$ antinuclear antibody; $\alpha C L=$ anticardiolipin antibody; dsDNA=double stranded DNA; SS-A=Sjögren's syndrome $A ; \alpha$-mito=antimitochondrial antibody; SLE=systemic lupus erythematosus; $\mathrm{H}=$ homogeneous staining; Nuc=nucleolar staining, $\mathrm{N}=$ normal; $\mathrm{ND}=$ not done.

matosus; $H=$ homogeneous staining; Nuc=nucleolar staining
$\ddagger+=$ weak positive; $++=$ positive $;+++=$ strong positive.

of the six patients in remission were ANA positive.

A clinical diagnosis of SLE could only be made in one patient (No 1), who has been reported in more detail elsewhere. ${ }^{6}$ She is the only patient in this study to have antibodies to DNA (dsDNA and ssDNA), SS-A, and nRNP, as well as having high titres of antibodies to cardiolipin and a strongly positive rheumatoid factor. Otherwise no clinical features of connective tissue disease were found apart from patient 5, who had had Still's disease as a child, and patient 13 who had had mild arthralgias for two to three years associated with antimitochondrial antibodies. The patient with nucleolar ANA staining had no features of scleroderma, but had breast carcinoma and diuretic induced gout.

Most of the ANA positive patients had a high ESR and three patients had raised immunoglobulin concentrations, two to three times the upper limit of normal (table 2). Significant titres of anticardiolipin antibodies were found in five patients, but there was no obvious relation with ANA positivity or activity of the porphyria. No clinical or immunological abnormalities were found in any of the patients with latent acute intermittent porphyria.

Further characterisation to ascertain whether the positive fluorescence was due to antihistone

Table 3: Results of immunofluorescence to assay for antibodies to histones in antinuclear antibody positive patients with acute intermittent porphyria*

\begin{tabular}{|c|c|c|c|c|}
\hline \multirow{2}{*}{$\begin{array}{l}\text { Patient } \\
\text { No }\end{array}$} & \multirow{2}{*}{$\begin{array}{l}H E p_{2} \\
\text { cells }\end{array}$} & \multicolumn{3}{|l|}{ Rat liver } \\
\hline & & $\stackrel{(a)}{\text { Untreated }}$ & $\begin{array}{l}\text { (b) } \\
\text { Acid } \\
\text { eluted }\end{array}$ & $\begin{array}{l}\text { (c) } \\
\text { Histone } \\
\text { reconstituted }\end{array}$ \\
\hline $\begin{array}{l}1 \\
2 \\
3 \\
4 \\
5 \\
6 \\
7 \\
8\end{array}$ & $\begin{array}{c}+++(\mathbf{H}) \\
++(\mathbf{H}) \\
+(\mathbf{H}) \\
+(\mathbf{H}) \\
++(\mathbf{H}) \\
+(\mathbf{H}) \\
+(\mathbf{H}) \\
+++(\mathbf{N u c})\end{array}$ & $\begin{array}{c}+++(\mathbf{H}) \\
+++(\mathbf{H}) \\
+(\mathbf{H}) \\
+(\mathbf{H}) \\
++(\mathbf{H}) \\
+(\mathbf{H}) \\
+(\mathbf{H}) \\
+++ \text { (Nuc) }\end{array}$ & $\begin{array}{l}+++(\mathrm{H}) \\
- \\
- \\
- \\
- \\
- \\
- \\
+++(\mathrm{Nuc})\end{array}$ & $\begin{array}{l}+++(\mathrm{H}) \\
- \\
- \\
- \\
- \\
- \\
+++(\mathrm{Nuc})\end{array}$ \\
\hline
\end{tabular}

*Staining of serum on untreated (a) rat liver was comparable with that on $\mathrm{HEp}_{2}$ cells. In patients 2-7 staining was eluted with $0 \cdot 1 \mathrm{~N} \mathrm{HCl} \mathrm{(b)} \mathrm{and} \mathrm{was} \mathrm{not} \mathrm{present} \mathrm{on} \mathrm{acid} \mathrm{eluted} \mathrm{but} \mathrm{histone}$ $2-7$ staining was eluted with $0 \cdot 1 \mathrm{~N} \mathrm{HCl}$ (b) and was
reconstituted sections (c). (Method after Tan et $a l^{7}$.)

Staining patterns: $\mathbf{H}=$ homogeneous; Nuc=nucleolar; $+=$ weak positive; $++=$ positive; $+++=$ strong positive; $-=$ negative. antibodies showed that antibodies to the histone fractions commonly found in autoimmune diseases (1, 2a, and 2b), which would have given a positive stain on the reconstituted sections, were not present in any of these patients (table 3 ). The reaction pattern in patients 2-7 was compatible with antibodies to histone fractions 3 and 4 , but other nuclear antigens giving similar acid elutable reactions cannot be excluded. The ANA positive reactions in patients 1 and 8 are due to anti-dsDNA and an antinucleolar antibody respectively.

Addition of pathological concentrations of $\delta$ aminolaevulinic acid or porphobilinogen did not induce positive immunofluorescence on $\mathrm{HEp}_{2}$ cells in either the ANA negative sera from patients with acute intermittent porphyria or in normal controls, suggesting that increased levels of these porphyrin precursors alone are not responsible for the positive reactions in acute intermittent porphyria. Positive immunofluorescence in serum from patients with acute intermittent porphyria or SLE was not influenced by addition of $\delta$-aminolaevulinic acid or porphobilinogen.

Clinical and laboratory indices suggesting a coexistent connective tissue disease were absent from all the patients with porphyria cutanea tarda, erythropoietic protoporphyria, variegate porphyria, and hereditary coproporphyria, apart from one patient with erythropoietic protoporphyria in whom an isolated speckled ANA was found on immunofluorescence. All of these patients had had clinically manifest disease, but none of the patients with variegate porphyria or hereditary coproporphyria had had a recent acute attack.

\section{Discussion}

The porphyrias have been described in association with a variety of autoimmune disorders. ${ }^{8}$ Two previous studies have failed to show an increased incidence of connective tissue disease in patients with porphyria cutanea tarda, though non-specific immunological abnormalities, such as raised ESR and immunoglobulins, were common. ${ }^{9} 10$ Although the association of SLE 
and acute porphyria has been described in several case reports, there have been no previous studies including patients with acute porphyria.

The clinical manifestations of acute intermittent porphyria and SLE may be remarkably alike with a similar age of onset and predominance of women affected. Factors such as drugs, intercurrent infections, and hormonal changes may precipitate either disease. The main symptoms in acute intermittent porphyria-namely, limb pain, neuropathies, central nervous system and psychiatric manifestations, and abdominal pain, may all be features of SLE. In addition, fever, anaemia, renal failure, and hypertension are common to both disorders. Immunologically mediated cutaneous photosensitivity is common to the other porphyrias $^{811}$ and SLE but does not occur in acute intermittent porphyria.

This study shows that although antinuclear antibodies may be present in more than $50 \%$ of patients with active acute intermittent porphyria, the incidence of overt clinical inflammatory connective tissue disease does not seem to be increased in our porphyric patients. The finding of a positive ANA test in many patients with acute intermittent porphyria may lead to the false impression that some of these patients also have SLE. In view of the clinical difficulties in differentiating these disorders, strict criteria, including the presence of antibodies to double stranded DNA, are therefore necessary before a diagnosis of SLE can be confidently made in a patient with porphyria. This might not have been done in several of the previous case reports, resulting in an overdiagnosis of SLE.

The presence of ANAs in acute intermittent porphyria, which were not found in latent disease, might conceivably appear following cell damage after an acute porphyric attack. Our preliminary studies, however, suggest that induction of ANA is unlikely to be due solely to increased concentrations of $\delta$-aminolaevulinic acid or porphobilinogen. Whether the incidence of ANAs is also increased in the other types of acute porphyria will need more extensive study, as none of our patients with variegate porphyria and hereditary coproporphyria had had a recent acute attack.

This study suggests that the coexistence of SLE and porphyria in a patient is probably a chance occurrence. In some patients in whom the diagnosis of SLE is in doubt, particularly those with central nervous system involvement and negative tests for dsDNA, however, it may be of clinical value to consider porphyria as an alternative diagnosis and measure urinary porphyrins as a screening test.

The authors are grateful to Professor G H Elder, University of Wales College of Medicine, Cardiff and Dr J L M Hawk, Institute of Dermatology, London, for allowing their patients to be included in this study.

1 Wolfram S. Uber porphyrinkolik: ein beitrag zur symptomatologic des erythematodes acutus. Hautarzt 1952; 3:

2 Harris M Y, Mills G C, Levin W C. Coexistent systemic lupus erythematosus and porphyria. Arch Intern Med 1966 117: $425-8$.

3 Hetherington G W, Jetton R L, Knox J M. The association of lupus erythematosus and acute intermittent porphyria. $\mathrm{Br} \mathcal{F}$ Dermatol 1970; 82: 118-24.

4 Cram D L, Epstein J H, Tuffanelli D L. Lupus erythematosus and porphyria: coexistence in seven patients. Arch Dermatol 1973; 108: 779-84.

5 Rosemarin J I, Nigro E J, Levere R D, Mascarenhas B R. Systemic lupus erythematosus and acute intermittent porphyria: coincidence or association. Arthritis Rheum 1982; 25: 1134-7.

6 Allard S A, Scott J T. Systemic lupus erythematosus and acute intermittent porphyria. Br $\mathcal{f}$ Rheumatol 1989; 28:

7 Tan E M, Robinson J, Robitaille P. Studies of antibodies to histones by immunofluorescence. Scand F Immunol 1976; 5 : histones

8 Kappas A, Sassa S, Anderson K E. The porphyrias. In: Stanbury J B, Wyngaarden J B, Fredrickson D S, et al, eds. The metabolic basis of inherited disease. 5th ed. New York: McGraw-Hill, 1983: 1301-84.

9 Tio T H, Leynse B, Feltkamp T E, Neumann H. Autoimmunity and cutaneous porphyria. S Afr $\mathcal{F}$ Lab Clin Med 1971; 17: 199-201.

10 Clemmensen O, Thomsen K. Porphyria cutanea tarda and systemic lupus erythematosus. Arch Dermatol 1982; 118: $160-2$.

$11 \mathrm{Lim} \mathrm{H} \mathrm{W}$, Gigli I. The role of complement in porphyrininduced photosensitivity. $\mathcal{F}$ Invest Dermatol 1981; 76: 4-9. 